\title{
Tubulin Alpha-1B Chain
}

National Cancer Institute

\section{Source}

National Cancer Institute. Tubulin Alpha-1B Chain. NCI Thesaurus. Code C115194.

Tubulin alpha-1B chain (451 aa, $\sim 50 \mathrm{kDa}$ ) is encoded by the human TUBA1B gene. This protein plays a role in microtubule structure. 